Andrzej Dakowicz

Uniwersytet w Biatymstoku

\title{
Świadomość osobistych przekonań małżonków o wyższym i niższym poziomie zadowolenia ze swojego związku
}

\section{AWARENESS OF PERSONAL BELIEFS SPOUSES WITH HIGHER AND A LOWER LEVEL OF SATISFACTION WITH THEIR RELATIONSHIP}

200 married couples were studied using The Questionnaire Chosen Marriages and constructed in accordance with psychotransgressive network theory of personality Test Conscious Personal Beliefs. Were isolated of them two groups of 100 spouses with higher and lower levels of satisfaction with their relationship. Comparative analysis of the results showed that husbands and wives with higher levels of satisfaction with their relationship have a much greater awareness of personal beliefs than husbands and wives with a lower level of satisfaction with the marriage. The obtained result encourages further exploration of psychological determinants of the success of the marriage in the psychotransgressive mainstream, paying attention to the specificity of the effect of other psychons and their network interdependence.

Key words: psychotransgressionism, network theory of personality, personal psychon, awareness of personal beliefs, satisfaction with marriage.

\section{Wprowadzenie}

Sposób funkcjonowania ludzkiej psychiki kształtuje myślenie, przeżywanie i postępowanie człowieka wobec otaczającego go świata. 
Tworzenie, utrzymywanie i rozwój bliskich relacji interpersonalnych tłumaczone jest na różne sposoby ze względu na przyjęte ujęcie teoretyczne. Biologiczny sposób podejścia poszukuje przyczyn ludzkiego zachowania w działaniu genów, mózgu, układu nerwowego, a także odwołuje się do procesów wydzielania wewnętrznego regulującego gospodarkę hormonalną ${ }^{1}$. Zgodnie $\mathrm{z}$ ujęciem psychodynamicznym wszelkie zachowania i przeżycia człowieka zdeterminowane są siłami popędowymi, nad którymi nie ma kontroli. Siła popędowa powoduje wzrost pobudzenia, odczuwanego jako pragnienie, co zachęca do określonej aktywności powodującej redukcję napięcia i uzyskanie ulgi. Człowiek dąży do przyjemności i unika przykrości². Według podejścia behawiorystycznego warunki środowiskowe determinują ludzkie zachowania będące głównym przedmiotem badań, czynnościami, które trzeba zrozumieć, przewidywać i sterować ${ }^{3}$. Zgodnie z podejściem humanistycznym, ludzie są istotami aktywnymi, dobrymi z natury, posiadającymi zdolność dokonywania wyboru, których głównym zadaniem jest dążenie do powiększenia i rozwoju swojego potencjału ${ }^{4}$. Koncepcja poznawcza opierając się na wielu paradygmatach badawczych skupia się na poznaniu i wyjaśnianiu mechanizmów zbierania informacji, kodowania, przechowywania, interpretowania i wyrażania ich w ciągu ludzkiego życia ${ }^{5}$. Podejście ewolucjonistyczne skupia się na adaptacyjności zachowania i umysłu w perspektywie upływających milionów lat, jako drodze do przetrwania człowieka w świecie fizycznym i społecznym ${ }^{6}$. Nowym ujęciem ludzkiej psychiki jest skoncentrowany na zmianie i rozwoju psychotransgresjonizm opracowany przez J. Kozieleckiego. Autor sposób funkcjonowania struktury psychicznej człowieka wyjaśnia w oparciu o pojęcie granicy i jej przekraczanie,

1 L. Kaczmarek, Biologia molekularna przetwarzania informacji przez komórki nerwowe, [w:] Mózg a zachowanie, T. Górska, A. Grabowska, J. Zagrodzka (red.), Warszawa 2012, s. 9-24; J. Matysiak, Psychologia fizjologiczna, [w:] Psychologia. Podręcznik akademicki, t. 1, J. Strelau (red.), Gdańsk 2000, s. 95-129; H. Walum, L. Westberg, S. Henningsson i in., Genetic variation in the vasopressin receptor 1a gene (AVPR1A) associates with pair-bonding behavior in humans, "Proceedings National Academy of Sciences USA" 105(2008), s. 14153-14156.

P. K. Oleś, Wprowadzenie do psychologii osobowości, Warszawa 2011, s. 41-47.

P. G. Zimbardo, Psychologia i życie, Warszawa 1999, s. 522-528.

A. H. Maslow, Motywacja i osobowość, Warszawa 1990, s. 72-101.

R. Stachowski, B. Dobroczyński, Historia psychologii - od Wundta do czasów najnowszych, [w:]Psychologia. Podręcznik akademicki, t. 1, J.Strelau, D. Doliński (red.), Gdańsk 2008, s. 106-107.

D. M. Buss, Psychologia ewolucyjna, Gdańsk 2001. 
zachowania ochronne i transgresyjne, a także proponuje nowe, sieciowe ujęcie osobowości ${ }^{7}$.

Ludzie w cyklu życia przejawiają skłonność do wyznaczania granic, które zgodnie z kulturowym obrzędem przejścia - inicjacją, małżeństwem, konfirmacją, inauguracją - rytualnie przekraczają zmieniając swoją egzystencję ${ }^{8}$. Według A. H. Maslowa ${ }^{9}$ człowiek dążąc do zaspokojenia najwyższej potrzeby samorealizacji przekracza swoje dotychczasowe możliwości rozwoju psychologicznego i duchowego. W ujęciu logoteorii, opartej na logoterapii V. E. Frankla, człowiek posiada psychiczną zdolność do jednoczesnego życia w trzech wymiarach czasowych, równoczesnego intelektualnego i emocjonalnego przeżywania siebie i otoczenia oraz możliwość przekraczania tych uwarunkowań ${ }^{10}$. Dojrzała jednostka bieżącą treść życia psychicznego tworzy z dorobku przeszłości, z wizji przyszłości w sytuacji teraźniejszej. Różne okoliczności egzystencjalne mogą łączenie teraźniejszości z przeszłością lub przyszłością przedłużać w czasie lub wręcz zrywać te związki, albo nadmiernie akcentować któryś z wymiarów czasowych ${ }^{11}$. Podobnie proces rozwoju człowieka ujmuje M. Grzywak-Kaczyńska ${ }^{12}$, która zwraca uwagę na własny udział człowieka w swoim rozwoju poszerzający granice realizacji potrzeb rozwojowych podporządkowujących sobie potrzeby biologiczne. Autorka zauważa, że normalne dziecko od początku życia przejawia tendencje do rozwoju jako dążenie do nieustannego przekraczania swego obecnego stanu.

Funkcjonując w świecie człowiek potrzebuje pewnych wartości materialnych, intelektualnych i duchowych. Ich niedobór zaburza homeostazę i skłania do podjęcia działań ochronnych (zachowawczych). W odniesieniu do małżeństwa będą to czynności związane $\mathrm{z}$ codziennym funkcjonowaniem, np. zaangażowanie w wykonywaną pracę i obowiązki domowe. Pozwalają osiągnąć zdrowie fizyczne i psychiczne, wzmacniają wiarę we własne siły i możliwości przystosowania się. Nie pozwalają jednak na przekształcanie rzeczywistości, burzenie i rozwój nowych struktur, nie prowadzą ku kształtowaniu ludzkiej

7 J. Kozielecki, Psychotransgresjonizm. Nowy kierunek psychologii, Warszawa 2007, s. 33-141.

$8 \quad$ E. O. Wilson, O naturze ludzkiej, Poznań 1998.

A. H. Maslow, Motywacja..., dz. cyt., s. 153.

V. E. Frankl, Homo Patiens. Próba wyjaśnienia sensu cierpienia, Warszawa 1984, s. 147-148.

K. Popielski, Noetyczny wymiar osobowości. Psychologiczna analiza poczucia sensu życia, Lublin 1994, s. 258-261. 
osobowości ${ }^{13}$. Natomiast zachowania transgresyjne związane są z ekspansją, twórczością, dążeniem do zwiększenia władzy i mają pewne cechy wspólne decydujące o ich swoistości oraz jednolitości. Są nimi wykraczanie poza dotychczasowe osiągnięcia osoby oraz wzbogacenie indywidualnego „być” i ,mieć” w to, co do tej pory było transcendentne wobec jednostki. Zachowania transgresyjne w przypadku uzyskania zamierzonego wyniku kończą się powodzeniem, ale zdarza się tak, że działający podmiot doznaje niepowodzenia, ponieważ ryzyko jest immanentną cechą transgresji ${ }^{14}$. Jednak podejmowanie działań transgresyjnych stwarza więcej potencjalnych okazji, aby poznać siebie, współmałżonka i lepiej zrozumieć otaczającą rzeczywistość. Otwiera to drogę ku temu, by w relacji małżeńskiej sprawniej posługiwać się nabytymi kompetencjami w rozpoznawaniu pojawiających się trudności, szukaniu ich przyczyn i podejmowaniu wspólnych działań zmierzających do ich przezwyciężenia doświadczając przez to radości łączącej oboje małżonków. Tym, co pomaga skutecznie realizować tego typu działania jest wyższa potencjalna moc psychonów tworzących sieciową strukturę osobowości żony i męża, a także większa siła powiązań między nimi. Dzięki temu tworzą sprawnie działające sieci, zdolne efektywnie funkcjonować w nieustannie zmieniającej się rzeczywistości życia małżeńskiego. Najkrócej rzecz ujmując, osobowość stanowi sieć pięciu względnie trwałych i równoważnych składników psychicznych, zwanych psychonami: poznawczy (PP), instrumentalny (PI), motywacyjny (PM), emocjonalny (PE) i osobisty (PO). Wpływa ona na kierunek życia i wzorce zachowania, jego unikatowość oraz spójność, stałość w rozmaitych sytuacjach i w różnym czasie. Wewnątrz psychonów, jak i między nimi, znajdują się powiązania umożliwiające przepływ informacji i energii, dzięki czemu osobowość funkcjonuje jako pewna całość posiadająca poczucie tożsamości i zdolność wchodzenia w interakcje ze środowiskiem ${ }^{15}$.

\footnotetext{
$13 \quad$ J. Kozielecki, Psychotransgresjonizm..., dz. cyt., s. 39.

14 Tenże, Działania transgresyjne: przekraczanie granic samego siebie, „Przegląd Psychologiczny" 3(1983), s. 506.

15 J. Kozielecki, Psychotransgresjonizm..., dz. cyt., s. 123-141.
} 


\section{Świadomość osobistych przekonań jako istotna część psychonu osobistego będącego elementem sieciowej struktury osobowości}

Psychon osobisty w swoim rozumieniu zbliżony jest do ja przedmiotowego związanego z samowiedzą i obrazem samego siebie ${ }^{16}$, którego treść wpływa na formy angażowania się $\mathrm{w}$ relacje $\mathrm{z}$ innymi ${ }^{17}$. $\mathrm{W}$ pewnym sensie wyraża się $\mathrm{w}$ perspektywie noetycznej, jako ramie poznawczej zawierającej treści noetyczne, przez które człowiek spostrzega siebie oraz innych i otaczającą go rzeczywistość. Dzięki temu modyfikowane jest jego funkcjonowanie psychiczne i zachowania społeczne ${ }^{18}$. Stanowi głęboką strukturę neurofizjologiczną, psychiczną i duchową, w której znajdują się treści egzystencjalno-tożsamościowe dotyczące osoby ludzkiej ${ }^{19}$. Są one zakodowane w świadomych przekonaniach i w prawie niewyrażalnych stanach świadomych (poczuciach). Najważniejsze z nich to: przekonanie o własnym istnieniu jako osoby i bytu sprawczego („istnieję”, „jestem osobą”, ,jestem sprawcą"); przekonanie o afirmacji świata (,,jeśli żyję, akceptuję go w całości, łącznie z własną osobą”); przekonanie o własnej jedności i integralności (,jestem niepodzielną całością”); przekonanie o swojej ciągłości („zmieniają się okoliczności, a ja przez całe życie jestem sobą”); przekonanie o niepowtarzalności własnej osoby (,czuję się różnym i odrębnym od innych, ale kontaktuję się z nimi, którzy są również unikatowymi osobami" ${ }^{20}$.

Celem prezentowanych badań jest próba poszukiwania czynników psychicznych modyfikujących jakość relacji małżeńskiej w nowym, psychotransgresyjnym ujęciu. Ponieważ jest to wstępny etap badań, skupiono się na jednym z psychonów - osobistym - zakładając występującą zależność pomiędzy zadowoleniem z małżeństwa a świadomością osobistych przekonań małżonków. Przeprowadzona do tej pory analiza skłania ku sformułowaniu następujących hipotez:

16

17

Tamże, s. 135.

M. Jarymowicz, W stronę indywidualnej podmiotowości i zbliżeń z innymi: podmiotowe podstawy spolecznychidentyfikacji,[w:]Poza egocentryczna perspektywa widzenia siebie i świata, M. Jarymowicz (red.), Warszawa 1994, s. 11-33.

J. Różycka, K. Skrzypińska, Perspektywa noetyczna $w$ psychologicznym funkcjonowaniu człowieka, „Roczniki Psychologiczne” 2(2011), s. 101-121.

M.Jarymowicz,Psychologia tożsamości,[w:]Psychologia.Podręcznikakademicki, t. 3, J. Strelau (red.), Gdańsk 2000, s. 107-125; M. Kofta, D. Doliński, Poznawcze podejście do osobowości, [w:] Psychologia. Podręcznik akademicki, t. 2, J. Strelau (red.), Gdańsk 2000, s. 561-600.

J. Kozielecki, Psychotransgresjonizm..., dz. cyt., s. 136. 
H1: Żony o wyższym poziomie zadowolenia z małżeństwa charakteryzują się większą świadomością osobistych przekonań niż żony o niższym poziomie zadowolenia z małżeństwa.

H2: Mężowie o wyższym poziomie zadowolenia z małżeństwa charakteryzują się większą świadomością osobistych przekonań niż mężowie o niższym poziomie zadowolenia z małżeństwa.

Prowadzone $\mathrm{w}$ ujęciu psychotransgresyjnym badania mają przede wszystkim charakter eksploracyjny, pozwalający ze względu na uzyskane wyniki ustalić ewentualne kierunki dalszych, bardziej szczegółowych poszukiwań czynników wpływających na jakość relacji małżeńskich.

\section{Metoda badawcza}

Dobór badanych małżeństw oraz narzędzi pomiaru poziomu zadowolenia z małżeństwa i pomiaru świadomości osobistych przekonań małżonków został powiązany z określonymi założeniami operacyjnymi biorącymi pod uwagę główne założenia psychotransgresjonizmu.

Badaniami objęto 200 par, będących w pierwszym formalnym związku małżeńskim z minimum 5-letnim stażem, posiadających wykształcenie średnie lub wyższe, aktywnych zawodowo i pełniących funkcje rodzicielskie. Przyjęcie powyższych kryteriów zmierzało ku jak największemu ujednoliceniu grupy badanych, aby zminimalizować modyfikujący wpływ na poziom świadomych osobistych przekonań innych zmiennych niż kontrolowana zmienna niezależna - poziom zadowolenia badanych małżonków ze swojego związku. Na podstawie wyniku uzyskanego w Kwestionariuszu Dobranego Małżeństwa $(\mathrm{KDM}-2)^{21}$ wyodrębniono grupę 100 żon i grupę 100 mężów o wyższym poziomie zadowolenia z małżeństwa oraz grupę 100 żon i grupę 100 mężów o niższym poziomie zadowolenia z małżeństwa. Szczegółowe dane na temat badanych małżonków zawiera tabela 1 .

${ }_{21}$ M. Plopa, Więzi w matżeństwie i rodzinie. Metody badań, Kraków 2005, s. 51-106. 
Tabela 1. Charakterystyka badanych małżonków

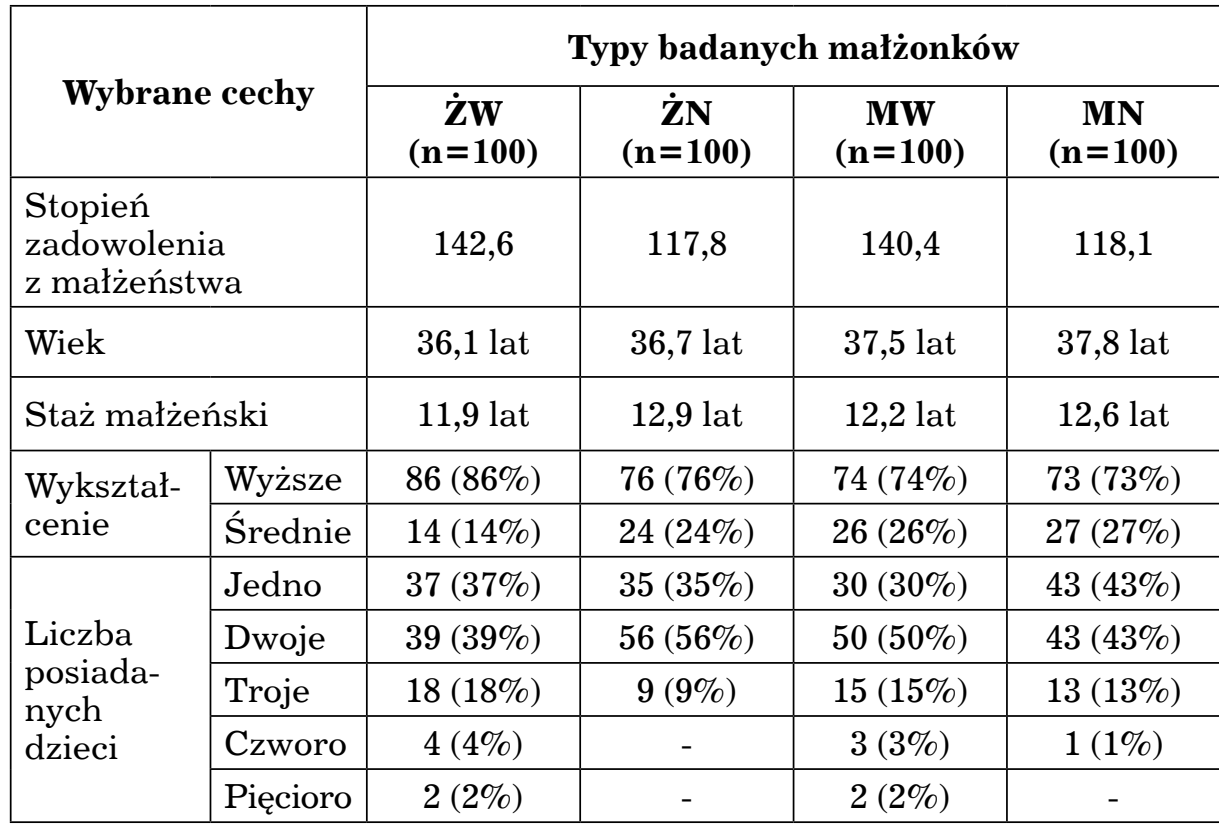

Objaśnienia: ŻW - żony o wyższym poziomie zadowolenia z małżeństwa; $\dot{Z} N$ - żony o niższym poziomie zadowolenia z małżeństwa; $\mathrm{MW}$ - mężowie o wyższym poziomie zadowolenia z małżeństwa; $\mathrm{MN}$ - mężowie o niższym poziomie zadowolenia z małżeństwa

Poziom świadomości osobistych przekonań określono przy wykorzystaniu Testu Świadomych Osobistych Przekonań, który treściowo bardzo ściśle nawiązuje do założeń teoretycznych psychotransgresjonizmu odnośnie do istoty psychonu osobistego. Badani małżonkowie wyrażali swoje przekonania $\mathrm{w}$ odniesieniu do poszczególnych elementów psychonu osobistego wyrażonych w siedmiu twierdzeniach na pięciostopniowej skali ${ }^{22}$.

Przykładowe twierdzenia z Testu Świadomych Osobistych Przekonań wraz ze skalą odpowiedzi do wyboru:

1. Mam poczucie, że jestem osobą:

bardzo rzadko rzadko czasem często bardzo często

(4)

22 A. Dakowicz, Psychologiczna analiza matżonków o wysokim i niskim poziomie transgresji, [w:] T. Rostowska, A. Lewandowska-Walter (red.), Matżeństwo i rodzicielstwo a zdrowie, Toruń 2012, s. 91-93. 
4. Akceptuję świat w całości, łącznie z własną osobą:

bardzo rzadko rzadko czasem często
(1)
(2)
(3)
(4)

bardzo często

Teologia rodziny

6. Mimo zmieniających się okoliczności mam poczucie, że przez całe życie jestem sobą:
bardzo rzadko
rzadko
czasem
(3)
często
bardzo często
(2)
(4)

Ogólny poziom świadomych osobistych przekonań stanowi sumę zaznaczonych przez badanych małżonków wyborów przy poszczególnych twierdzeniach. Maksymalny możliwy wynik do osiągnięcia to 35 punktów, a minimalny 7 punktów. Im suma jest wyższa, tym poziom świadomych osobistych przekonań jest wyższy, im suma jest niższa, tym poziom świadomych osobistych przekonań jest niższy.

Opracowując uzyskane wyniki wykorzystano program komputerowy SPSS 21.0 PL for Windows, za pomocą którego obliczono wartość testu t-Studenta dla porównywanych małżonków o wyższym i niższym poziomie zadowolenia ze swojego związku ${ }^{23}$.

\section{Wyniki}

Żony o wyższym i niższym poziomie zadowolenia z małżeństwa istotnie różnią się między sobą pod względem świadomych osobistych przekonań. W zakresie czterech rodzajów przekonań (na siedem) żony o wyższym poziomie zadowolenia z małżeństwa uzyskały wartości znacznie większe niż żony o niższym poziomie zadowolenia $\mathrm{z}$ małżeństwa (tabela 2). W zakresie pozostałych trzech przekonań wartości uzyskane przez żony o wyższym poziomie zadowolenia z małżeństwa są nieco większe niż wartości uzyskane przez żony o niższym poziomie zadowolenia z małżeństwa (nie stwierdzono jednak pomiędzy badanymi grupami żon różnic istotnych statystycznie). Żony o wyższym poziomie zadowolenia $\mathrm{z}$ małżeństwa w porównaniu z żonami o niższym poziomie zadowolenia $\mathrm{z}$ małżeństwa mają silniejsze poczucie własnego istnienia $-t(198)=2,25 ; p<0,025$, znacznie większe poczucie sprawstwa podejmowanych przez siebie działań $-t(198)=2,47 ; p<0,014$, bardziej akceptują świat w całości, łącznie ze sobą $-t(198)=1,98$; $p<0,049$ i mają silniejsze poczucie bycia sobą, mimo zmieniających się okoliczności $-t(198)=3,64 ; p<0,000$. W zakresie wszystkich siedmiu

$23 \quad$ S. Bedyńska, A. Brzezicka, Statystyczny drogowskaz. Praktyczny poradnik analizy danych $w$ naukach spotecznych na przyktadach z psychologii, Warszawa 2007. 
osobistych przekonań ujmowanych razem, wartości uzyskane przez żony o wyższym poziomie zadowolenia $\mathrm{z}$ małżeństwa są znacznie większe niż wartości uzyskane przez żony o niższym poziomie zadowolenia $\mathrm{z}$ małżeństwa $-t(198)=2,84 ; p<0,005$.

Tabela 2. Porównanie wyników Testu Świadomych Osobistych Przekonań żon o wyższym i niższym poziomie zadowolenia z małżeństwa

\begin{tabular}{|c|c|c|c|c|c|c|}
\hline \multirow[t]{2}{*}{ Rodzaje poczuć } & \multicolumn{2}{|c|}{$\begin{array}{c}\text { Żony } \\
\text { o wyższym } \\
\text { poziomie } \\
\text { zadowolenia } \\
\text { z małżeństwa } \\
(n=100) \\
\end{array}$} & \multicolumn{2}{|c|}{$\begin{array}{c}\text { Żony } \\
\text { o niższym } \\
\text { poziomie } \\
\text { zadowolenia } \\
\text { z małżeństwa } \\
(\mathbf{n}=\mathbf{1 0 0}) \\
\end{array}$} & \multicolumn{2}{|c|}{$\begin{array}{l}\text { Istotnośćc } \\
\text { różnic }\end{array}$} \\
\hline & $\mathbf{M}$ & $\mathbf{S}$ & $\mathbf{M}$ & $\mathbf{S}$ & $\mathbf{t}$ & p $<$ \\
\hline Bycia osobą & 4,32 & 0,92 & 4,21 & 0,71 & 0,94 & n.i. \\
\hline Własnego istnienia & 4,53 & 0,69 & 4,31 & 0,69 & 2,25 & 0,025 \\
\hline $\begin{array}{l}\text { Sprawstwa podejmo- } \\
\text { wanych przez siebie } \\
\text { działań }\end{array}$ & 4,32 & 0,63 & 4,08 & 0,73 & 2,47 & 0,014 \\
\hline $\begin{array}{l}\text { Akceptacji świata w ca- } \\
\text { łości, łącznie z własną } \\
\text { osobą }\end{array}$ & 4,04 & 0,76 & 3,82 & 0,81 & 1,98 & 0,049 \\
\hline $\begin{array}{l}\text { Bycia niepodzielną } \\
\text { całością }\end{array}$ & 3,99 & 0,92 & 3,88 & 0,81 & 0,90 & n.i. \\
\hline $\begin{array}{l}\text { Bycia sobą, mimo } \\
\text { zmieniających się } \\
\text { okoliczności }\end{array}$ & 4,33 & 0,70 & 3,97 & 0,70 & 3,64 & 0,000 \\
\hline $\begin{array}{l}\text { Bycia różnym i odręb- } \\
\text { nym od innych, którzy } \\
\text { są również unikatowy- } \\
\text { mi osobami }\end{array}$ & 3,94 & 1,08 & 3,73 & 0,96 & 1,45 & n.i. \\
\hline Razem & 29,47 & 3,69 & 28,00 & 3,64 & 2,84 & 0,005 \\
\hline
\end{tabular}

Różnice między mężami o wyższym i niższym poziomie zadowolenia ze swojego związku pod względem świadomych osobistych przekonań są jeszcze większe niż różnice pomiędzy żonami o wyższym i niższym poziomie zadowolenia $\mathrm{z}$ małżeństwa. W zakresie sześciu rodzajów przekonań (na siedem) mężowie o wyższym poziomie zadowolenia z małżeństwa uzyskali wartości znacznie większe niż mężowie o niższym poziomie zadowolenia z małżeństwa (tabela 3 ). W zakresie siódmego przekonania, wartości uzyskane przez mężów o wyższym poziomie zadowolenia z małżeństwa, są nieco większe niż wartości uzyskane przez mężów o niższym poziomie zadowolenia z małżeństwa 
(nie stwierdzono jednak różnicy istotnej statystycznie pomiędzy grupami badanych mężów). Mężowie o wyższym poziomie zadowolenia z małżeństwa w porównaniu z mężami o niższym poziomie zadowolenia z małżeństwa mają silniejsze poczucie bycia osobą $-t(198)=$ 4,$01 ; p<0,000$, silniejsze poczucie własnego istnienia $-t(198)=4,87$; $p<0,000$, znacznie większe poczucie sprawstwa podejmowanych przez siebie działań $-t(198)=2,13 ; p<0,035$, bardziej akceptują świat w całości, łącznie ze sobą $-t(198)=4,27 ; p<0,000$, mają silniejsze poczucie bycia niepodzielną całością $-t(198)=2,47 ; p<0,014$ i mają silniejsze poczucie bycia sobą mimo zmieniających się okoliczności $-t(198)=$ 3,$23 ; p<0,001$. W zakresie siedmiu osobistych przekonań, wartości uzyskane przez mężów o wyższym poziomie zadowolenia z małżeństwa są znacznie większe niż wartości uzyskane przez mężów o niższym poziomie zadowolenia z małżeństwa $-t(198)=4,88 ; p<0,000$.

Tabela 3. Porównanie wyników Testu Świadomych Osobistych Przekonań mężów o wyższym i niższym poziomie zadowolenia z małżeństwa

\begin{tabular}{|c|c|c|c|c|c|c|}
\hline \multirow[t]{2}{*}{ Rodzaje poczuć } & \multicolumn{2}{|c|}{$\begin{array}{c}\text { Mężowie } \\
\text { o wyższym } \\
\text { poziomie } \\
\text { zadowolenia } \\
\text { z małżeństwa } \\
(\mathbf{n}=100) \\
\end{array}$} & \multicolumn{2}{|c|}{$\begin{array}{c}\text { Mężowie } \\
\text { o niższym } \\
\text { poziomie } \\
\text { zadowolenia } \\
\text { z małżeństwa } \\
(\mathbf{n}=100) \\
\end{array}$} & \multicolumn{2}{|c|}{$\begin{array}{l}\text { Istotność } \\
\text { różnic }\end{array}$} \\
\hline & $\mathbf{M}$ & $\mathbf{s}$ & $\mathbf{M}$ & $\mathbf{s}$ & $\mathbf{t}$ & $\mathbf{p}<$ \\
\hline Bycia osobą & 4,33 & 0,74 & 3,84 & 0,97 & 4,01 & 0,000 \\
\hline Własnego istnienia & 4,45 & 0,66 & 3,94 & 0,81 & 4,87 & 0,000 \\
\hline $\begin{array}{l}\text { Sprawstwa podejmo- } \\
\text { wanych przez siebie } \\
\text { działań }\end{array}$ & 4,25 & 0,67 & 4,04 & 0,72 & 2,13 & 0,035 \\
\hline $\begin{array}{l}\text { Akceptacji świata w ca- } \\
\text { łości, łącznie z własną } \\
\text { osobą }\end{array}$ & 4,28 & 0,67 & 3,82 & 0,84 & 4,27 & 0,000 \\
\hline $\begin{array}{l}\text { Bycia niepodzielną } \\
\text { całością }\end{array}$ & 3,99 & 1,06 & 3,63 & 1,00 & 2,47 & 0,014 \\
\hline $\begin{array}{l}\text { Bycia sobą, mimo } \\
\text { zmieniających się } \\
\text { okoliczności }\end{array}$ & 4,29 & 0,70 & 3,95 & 0,78 & 3,23 & 0,001 \\
\hline $\begin{array}{l}\text { Bycia różnym i odréb- } \\
\text { nym od innych, którzy } \\
\text { są również unikatowy- } \\
\text { mi osobami }\end{array}$ & 3,96 & 1,02 & 3,68 & 1,05 & 1,91 & n.i. \\
\hline Razem & 29,55 & 3,76 & 26,90 & 3,92 & 4,88 & $\mathbf{0 , 0 0 0}$ \\
\hline
\end{tabular}




\section{Podsumowanie i dyskusja wyników}

Obie przyjęte hipotezy zakładające większą świadomość osobistych przekonań małżonków o wyższym poziomie zadowolenia ze swojego związku niż małżonków o niższym poziomie zadowolenia ze swojego związku potwierdziły się odnośnie do wyniku całościowego i zdecydowanej większości wyników cząstkowych. W przypadku badanych żon różnica osiągająca poziom istotności statystycznej wystąpiła w czterech na siedem osobistych przekonań, natomiast w przypadku badanych mężów w sześciu na siedem osobistych przekonań.

Na zadowolenie z małżeństwa korzystnie wpływa świadomość osobistych przekonań małżonków. Im poziom świadomości osobistych przekonań jest wyższy, tym większe jest prawdopodobieństwo tworzenia satysfakcjonującego związku małżeńskiego. Wśród najistotniejszych świadomych osobistych przekonań, zarówno żon jak i mężów, znajduje się poczucie, że mimo zmieniających się okoliczności przez całe życie jestem sobą. Kryje się za tym przekonanie, że drogi życiowe mogą prowadzić do sukcesów i przeżywanej w związku z tym satysfakcji lub porażki w formie np. choroby, utraty pracy czy problemów wychowawczych ze swoimi dziećmi. Małżonkowie o wysokiej świadomości bycia sobą mimo zmieniających się okoliczności potrafią konstruktywnie przeżywać satysfakcję z osiągniętego sukcesu, pogłębiając wzajemną komunikację ${ }^{24}$, nierzadko planując dalsze działania potęgujące osiągnięty sukces. W przypadku przeżywanych trudności potrafią znosić dyskomfort psychiczny poszukując możliwych do zastosowania rozwiązań $^{25}$. Przeżywane trudności traktują jako okres przejściowy, po którym będzie lepiej, ponieważ już tego wcześniej doświadczyli i odnoszą się do problemów z pewnym dystansem. Można powiedzieć, że są przygotowani na potencjalne trudności, kiedy radują się sukcesem, co sprawia, że ich pojawienie się nie prowadzi do obezwładniającego dramatu życiowego, lecz jest traktowane jako zadanie ${ }^{26}$, które solidarnie rozwiązują oboje małżonkowie ${ }^{27}$.

Kolejnym świadomym osobistym przekonaniem, które charakteryzuje małżonków zadowolonych ze swojego związku jest poczucie sprawstwa podejmowanych przez siebie działań. To, że tak, a nie

$24 \quad$ M. Braun-Gałkowska, Psychoprofilaktyka życia rodzinnego, [w:] I. Janicka, T. Rostowska (red.) Psychologia w stużbie rodziny, Łódź 2003, s. 13.

M. Braun-Gałkowska, Psychologia domowa, Lublin 2008, s. 126.

E. Sujak, Życie jako zadanie, Warszawa 1989, s. 166.

A. T. Beck, Miłość nie wystarczy. Jak rozwiazywać nieporozumienia i konflikty matżeńskie, Poznań 1996, s. 244-262; Ch. Sautter, A. Sautter, Gdy opadna maski. Terapia związów, Poznań 2010, s. 211-222. 
inaczej układa się w naszym małżeństwie nie jest spowodowane tym, że tak działa współmałżonek, takie są dzieci albo tak wygląda rzeczywistość, na którą nie ma się wpływu. Tak w pewnych konkretnych sytuacjach może być, ale małżonkowie o wysokim poczuciu sprawstwa autonomicznie diagnozują sytuację. Potrafią wyjść poza własne potrzeby i pragnienia ${ }^{28}$, najpierw przyglądają się sobie i udzielają odpowiedzi czy to, że dana sytuacja tak, a nie inaczej wygląda nie jest związane z ich postępowaniem. Pozwala to w wielu przypadkach określić realne źródło aktualnych problemów, które rozwiązują modyfikując osobiste postępowanie. W porę podjęta refleksja zwiększa szansę na trafną diagnozę pozwalając podjąć właściwe działania. Wysokie poczucie sprawstwa podejmowanych przez siebie działań wpływa na wzrost odpowiedzialności za to, co się mówi i co się robi, nie oglądając się na współmałżonka w miarę swoich możliwości podejmując aktywność, która może korzystnie wpłynąć na atmosferę życia małżeńsko-rodzinnego.

Małżonkowie o wyższym poziomie zadowolenia z małżeństwa charakteryzują się silnym poczuciem własnego istnienia, bytowania na tym świecie. Kryje się tu pewien dystans wobec doczesności i otaczającego świata. Można powiedzieć, że wyższy poziom poczucia własnego istnienia pozwala postrzegać doświadczaną na co dzień rzeczywistość jako coś, co nie tyle przytłacza, ogranicza, co raczej skłania ku poszukiwaniu sensu i znaczenia osobistego istnienia na tym świecie ${ }^{29}$. Zmierzanie ku odkryciu sensu własnego istnienia, a szczególnie dokonanie tego, w wielu przypadkach na tyle modyfikuje relację małżeńską, że stanowi ona zupełnie nową, lepszą jakość ${ }^{30}$.

Korzystnie na zadowolenie z małżeństwa wpływa również świadomość poczucia akceptacji świata w całości, łącznie z własną osobą. Akceptacja otaczającego świata, tego, co się podoba i tego, co się nie podoba jak również siebie jest fundamentem pozwalającym na dokonywanie trwałych, pożądanych $z_{\text {mian }}{ }^{31}$. Brak akceptacji otaczającego świata i siebie lub jej niski poziom nierzadko prowadzi do rozgoryczenia, wycofania, niezadowolenia, które mocno negatywnie odbija się na klimacie emocjonalnym życia małżeńskiego. Małżonkowie

Z. Chlewiński, Dojrzałość: osobowość, sumienie, religijność, Poznań 1991, s. 20.

K. Popielski, Logoteoria i logoterapia w kontekście psychologii wspótczesnej, [w:] Człowiek - pytanie otwarte. Studia z logoteorii i logoterapii, K. Popielski (red.), Lublin 1987, s. 48-53.

F. Holböck, Święci matżonkowie. Zwyczajne pary matżeńskie wszystkich wieków nadzwyczajnymi wzorami cnót, Częstochowa 2004.

P. K. Oleś, Wprowadzenie do psychologii..., dz cyt., s. 321. 
charakteryzujący się wysokim poczuciem akceptacji świata w całości, łącznie z własną osobą są w stanie przyjąć wszystko, co do nich dociera z zewnątrz jak również informacje o sobie i potraktować je jako stan aktualny, który w zależności od oczekiwań można zmodyfikować. Pozytywne informacje o świecie i sobie dają poczucie radości, satysfakcji, a negatywne stają się bodźcem skłaniającym do podjęcia odpowiednich działań, aby to, co niekorzystne uległo zmianie. W pewnym sensie małżonkowie o wysokim poczuciu akceptacji świata i siebie traktują otaczającą rzeczywistość i siebie jako potencjalny wyjściowy materiał rozwojowy, który wcześniej lub później zostanie udoskonalony dając doświadczenie życia w satysfakcjonującym związku małżeńskim.

Wyższy poziom świadomych osobistych przekonań małżonków stanowi wyraz ich własnej egzystencji i tożsamości ${ }^{32}$, który poprzez przekonanie o byciu sobą, mimo zmieniających się okoliczności, sprawstwie podejmowanych przez siebie działań, własnym istnieniu oraz akceptacji świata w całości, łącznie z własną osobą wpływa na ich aktywność wobec siebie, jak również otaczającego ich świata. Można powiedzieć, że kryje się tu źródło egzystencjalnej motywacji, często odwołującej się wprost do zasad religijnych ${ }^{33}$, która podtrzymuje podejmowane działania związane z życiem m.in. małżeńskim i rodzinnym, szczególnie wtedy, gdy trudno jest znieść bardzo niekorzystne warunki psychiczne lub fizyczne. Ustalona hierarchia przyjętych wartości pozwala doświadczać pewnej transcendencji nad chaosem nieprzewidywalnej rzeczywistości, co może stać się źródłem szczęścia. Aktywna świadomość umożliwiająca regularną recepcję wydarzeń i doświadczeń w otoczeniu współmałżonka pozwala na podejmowanie zachowań bardziej przemyślanych, a przez to dojrzalszych, które pozytywnie wpływają na wzrost poziomu funkcjonowania tworzonego związku małżeńskiego ${ }^{34}$. Brak poczucia więzi małżeńskiej, która sprawia, że małżonkowie bardziej stanowią „my” niż dwoje ludzi obok siebie, często niweczy efektywność działań. Może to być skutkiem np. braku akceptacji trudności, które pojawiły się w życiu małżeńsko-rodzinnym i niechęci do wspólnego działania, aby je przezwyciężyć. W konsekwencji prowadzi to do zmiany akcentu w relacji małżeńskiej, który w początkowej fazie wyraźnie artykułowany jest „chcę być z tobą” na pojawiający się w sytuacji przeżywanych trudności „muszę być z to-

\footnotetext{
$32 \quad$ M. Jarymowicz, W stronę..., dz. cyt., s. 12-13.

33 J. Manjackal, Raj odzyskany. Moc chrześcijańskiego matżeństwa, Monachium 2011, s. 31 .

34 J. Rostowski, T. Rostowska, Matżeństwo i miłość. Kontekst psychologiczny i neuropsychologiczny, Warszawa 2014, s. 333.
} 
bą" ${ }^{35}$. Nierzadko silne poczucie sensu podejmowanych działań przez małżonków, chociaż rzeczywistość i docierające opinie z otoczenia dają znikome szanse na powodzenie przedsięwzięcia, po przejściowych, czasami wręcz dramatycznych zdarzeniach, umożliwia ostateczne osiągnięcie upragnionego celu, który na różne sposoby małżonków wzbogaca. Taki sposób funkcjonowania charakterystyczny jest dla osób o aktywnej sferze noetycznej. Istnieje wiele danych empirycznych wskazujących na pozytywną zależność pomiędzy wysoką aktywnością noetyczną a poczuciem sensu życia i zdrowiem psychicznym ${ }^{36}$. Małżonkowie o wyższym poziomie świadomości osobistych przekonań dysponują potencjałem, którego wykorzystanie może znacznie zwiększyć jakość tworzonego przez nich związku.

\section{Zakończenie}

Świadomość osobistych przekonań małżonków istotnie łączy się $\mathrm{z}$ poziomem ich zadowolenia z tworzonego związku. Ponieważ jest to wstępny, eksploracyjny etap badań w ujęciu psychotransgresyjnym warto podjąć badania dotyczące pozostałych psychonów. W kontekście przedstawionej analizy uzyskanych wyników rodzi się pytanie, na które warto poszukiwać odpowiedzi. Czy poziom zadowolenia z małżeństwa wpływa na większą świadomość osobistych przekonań małżonków, czy też bardziej świadomi swoich osobistych przekonań małżonkowie charakteryzują się wyższym poziomem zadowolenia ze swojego związku? W prezentowanych badaniach żony i mężowie byli analizowani indywidualnie ze względu na poziom zadowolenia ze swojego związku. Warto pomyśleć na przyszłość o strategii analizy uzyskanych wyników na poziomie pary małżeńskiej. Tego typu zadanie jest trudne do realizacji w praktyce, ale daje szansę uchwycenia sieciowej współzależności zmiennych w parze małżeńskiej, co jest bliższe idei psychotransgresjonizmu.

Słowa kluczowe: psychotransgresjonizm, sieciowa teoria osobowości, psychon osobisty, świadomość osobistych przekonań, zadowolenie z małżeństwa.

\footnotetext{
35 W. Półtawska, Samo życie, Częstochowa 1994, s. 14. 